\title{
Antibacterial Effects of Fluoride in Streptococcus mutans Growth in Vitro
}

\author{
Yura Pradiptama ${ }^{1}$, Marijam Purwanta ${ }^{2 *}$, Harianto Notopuro ${ }^{2}$ \\ ${ }^{1}$ Faculty of Medicine, Universitas Airlangga, Surabaya, Indonesia \\ ${ }^{2}$ Department of Microbiology, Faculty of Medicine, Universitas Airlangga, Surabaya, Indonesia - Dr. Soetomo General \\ Hospital Surabaya, Indonesia
}

\section{A R T I C L E I N F O}

\section{Article history:}

Received 14 May 2019

Received in revised form 10 June 2019

Accepted 25 June 2019

Available online 30 June 2019

\section{Keywords:}

Steptococcus mutans,

Sodium fluorid,

Dilution test,

MBC,

MIC.

\section{*) Corresponding author:}

marijampurwanta@yahoo.com

\begin{abstract}
A B S T RA C T
Introduction: Streptococcus mutans is a gram-positive coccus commonly found in the human oral cavity and is a pathogen of dental caries. S. mutans known to form biofilm in infective endocarditis heart-valve. Fluoride usage known to reduce the risk of dental caries. This study aims to analyze how usage of fluoride in inhibiting $S$. mutans growth.

Methods: This study was an experimental study. Antibacterial activity test was performed to evaluate the minimum inhibitory concentration (MIC) using dilution method of sodium fluoride. The minimum bactericidal concentration $(\mathrm{MBC})$ was determined by culturing from the previous dilution test into Chocolate Agar Plate.

Results: MIC for sodium fluoride is $4,8 \mathrm{mg} / \mathrm{ml}$ and the MBC for sodium fluoride to $S$. mutans is 4,8 $\mathrm{mg} / \mathrm{ml}$. We found S. mutans growth in higher concentration than $19,2 \mathrm{mg} / \mathrm{ml}$.

Conclusion: S. mutans was inhibited in dilution test. Growth of the bacteria in higher concentration of sodium fluoride is explained with quasi-irreversible inhibtior effects of fluorida.
\end{abstract}

\section{Introduction}

Streptococcus spp. is the most common bacteria in mouth. This gram positive bacteria grows in facultative anaerobic environment. The most common species that we can found in our mouth is Streptococcus mutans. ${ }^{1}$ Bowden in 1996 found that plaque mainly composed from bacteria which lives in our mouth. ${ }^{2} S$. mutans believed to be the primary factors this process. It is said that $S$. mutans was the main reason in initiating dental caries by forming biofilm in dental lesion. ${ }^{3}$ $S$. mutans metabolized sucrose more efficient than any other commensal bacteria and it have a regulation system to stimulates carbohydrates conversion into acidic substance which help them to excel in making acidic environment in our mouth. ${ }^{4}$ On the other hand, this nature helps the development of plaque in our teeth by using the lactic acid the bacteria metabolized. ${ }^{5}$ It is also stated that cariogenic nature from $S$. mutans makes this bacteria an opportunistic infection. $S$. mutans also found in the biofilm from infective endocarditive heart valve. ${ }^{6}$ There are many ways for us in order to maintain our oral hygiene. Brushing our teeth is the most common and frequently used by us nowadays. ${ }^{7}$ Fluoride was the most common substance use in toothpaste. Sodium fluoride $(\mathrm{NaF})$, tin (II) fluoride $\left(\mathrm{SnF}_{2}\right)$, and sodium monofluorophosphate $\left(\mathrm{Na}_{3} \mathrm{PO}_{3} \mathrm{~F}\right)$ are the most common forms of fluoride use in toothpaste to prevent dental caries. Sodium fluoride effectively suppressed oral bacteria growth by inhibiting enzyme which have important role in glycolytic cycle. Enolase enzym which converting 2-phosphogycerate into phosphoenolpyruvate (PEP) is really important in metabolic process which keep $S$. mutans alive. The decrease of phosphoenolpyruvate will make the growth of this bacteria stutter. ${ }^{6}$ Because of the widely use of fluoride, we want to see its antibacterial effects to $S$. mutans growths in vitro for further evaluation usage of fluoride in oral hygiene.

\footnotetext{
Methods

This research was a laboratory experimental research conducted in Microbiology Laboratory at Faculty of Medicine, Airlangga University. Sodium fluoride was obtained from a chemical store in Yogyakarta. The $S$. mutans obtained from Microbiology Laboratory of Faculty of Medicine Airlangga University.

This research used 8 concentrations with 2 control tubes. $0.5 \mathrm{ml}$ S. mutans (0.5 McFarland) in Mueller-Hinton broth as positive control tubes and sodium fluoride $153,6 \mathrm{mg} /$ $\mathrm{ml}$ in Mueller-Hinton broth as negative control. Each tube contain serial dilution of sodium fluoride $153,6 \mathrm{mg} / \mathrm{ml}, 76,8$ $\mathrm{mg} / \mathrm{ml}, 38,4 \mathrm{mg} / \mathrm{ml}, 19,2 \mathrm{mg} / \mathrm{ml}, 9,6 \mathrm{mg} / \mathrm{ml}, 4,8 \mathrm{mg} / \mathrm{ml}, 2,4$ $\mathrm{mg} / \mathrm{ml}$, and $1,2 \mathrm{mg} / \mathrm{m}$ with $1 \mathrm{ml}$ S. mutans in Mueller-Hinton broth, respectively. All tubes then incubated in $37^{\circ} \mathrm{C}$ for 24 hours in the incubator with microaerophilic environment $\left(10 \% \mathrm{CO}_{2}\right)$ in candle jar method. Four times replication were conducted for high accuracy. The minimum inhibitory concentration (MIC) was determined by visually observing
} 
the lowest sodium fluoride concentration with no turbidity. For each tube that a have clear scheme will be cultured into Chocolate Agar Plate and incubated for another 24 hours in candle jar. Every Chocolate Agar Plate will be observed to see if there any growth of $S$. mutans from each culture that we make from the tubes to determine minimum bactericidal concentration (MBC).

\section{Results}

These are the results for dilution test to determine the minimum inhibitory concentration (MIC) for sodium fluoride to $S$. mutans. The MIC observed visually by comparing each tube with the positive control tube. We found that bacterial growth still found in tubes with $153,6 \mathrm{mg} / \mathrm{ml}, 76,3$ $\mathrm{mg} / \mathrm{ml}, 38,4 \mathrm{mg} / \mathrm{ml}, 2,4 \mathrm{mg} / \mathrm{ml}$, and 1,2 mg/ml concentration had the same turbidity as positive control tubes while tubes with 19,2 mg/ml, 9,6 mg/ml and 4,8 mg/ml concentration had same condition with negative control tubes. Then we plated $\mathrm{S}$. mutans, from each concentration into Chocolate Agar Plate to determine MBC. (Table 1) (Figure 1).

Minimum bactericidal concentration (MBC) visually observed from the culture to see if there any growth of bacteria. It was found that $153,6 \mathrm{mg} / \mathrm{ml}, 76,8 \mathrm{mg} / \mathrm{ml}, 38,4$ $\mathrm{mg} / \mathrm{ml}, 2,4 \mathrm{mg} / \mathrm{ml}$, and $1,2 \mathrm{mg} / \mathrm{ml}$ have $S$. mutans growth meanwhile in 19,2 mg/ml, 9,6 mg/ml, and $4,8 \mathrm{mg} / \mathrm{ml}$ could not be found any bacteria growth. We had constant result from four time replication. The minimum inhibitory concentration (MIC) for sodium fluoride was 4,8 mg/ $\mathrm{ml}$ and minimum bactericidal concentration (MBC) for sodium fluoride was $4,8 \mathrm{mg} / \mathrm{ml}$. It is concluded that sodium fluoride has bactericidal effects on certain concentration. (Table 2) (Figure 2).

Table 1. Sodium fluoride Dillution Test for MIC

\begin{tabular}{|c|c|c|c|c|c|c|c|c|c|c|}
\hline \multirow[b]{2}{*}{$\begin{array}{l}\text { Replication } \\
\text { No. }\end{array}$} & \multicolumn{8}{|c|}{ Sodium fluoride concentration } & \multicolumn{2}{|c|}{ Control } \\
\hline & $\begin{array}{c}153,6 \\
\mathrm{mg} / \mathrm{ml} \\
\text { (T1) }\end{array}$ & $\begin{array}{c}76,8 \\
\mathrm{mg} / \mathrm{ml} \\
(\mathrm{T} 2)\end{array}$ & $\begin{array}{c}38,4 \mathrm{mg} / \\
\mathrm{ml} \\
(\mathrm{T} 3)\end{array}$ & $\begin{array}{c}19,2 \mathrm{mg} / \\
\mathrm{ml} \\
(\mathrm{T} 4)\end{array}$ & $\begin{array}{c}9,6 \mathrm{mg} / \\
\mathrm{ml} \\
(\mathrm{T} 5)\end{array}$ & $\begin{array}{c}4,8 \mathrm{mg} / \\
\mathrm{ml} \\
\text { (T6) }\end{array}$ & $\begin{array}{c}2,4 \mathrm{mg} / \\
\mathrm{ml} \\
(\mathrm{T} 7)\end{array}$ & $\begin{array}{c}1,2 \mathrm{mg} / \\
\mathrm{ml} \\
(\mathrm{T} 8)\end{array}$ & $\begin{array}{c}\text { Positive } \\
(+)\end{array}$ & $\begin{array}{c}\text { Negative } \\
(-)\end{array}$ \\
\hline 1 & $\mathrm{X}$ & $\mathrm{X}$ & $\mathrm{X}$ & $\mathrm{O}$ & $\mathrm{O}$ & $\mathrm{O}$ & $\mathrm{X}$ & $\mathrm{X}$ & $\mathrm{X}$ & $\mathrm{O}$ \\
\hline 2 & $\mathrm{X}$ & $\mathrm{X}$ & $\mathrm{X}$ & $\mathrm{O}$ & $\mathrm{O}$ & $\mathrm{O}$ & $\mathrm{X}$ & $\mathrm{X}$ & $\mathrm{X}$ & $\mathrm{O}$ \\
\hline 3 & $\mathrm{X}$ & $\mathrm{X}$ & $\mathrm{X}$ & $\mathrm{O}$ & $\mathrm{O}$ & $\mathrm{O}$ & $\mathrm{X}$ & $\mathrm{X}$ & $\mathrm{X}$ & $\mathrm{O}$ \\
\hline 4 & $\mathrm{X}$ & $\mathrm{X}$ & $\mathrm{X}$ & $\mathrm{O}$ & $\mathrm{O}$ & $\mathrm{O}$ & $\mathrm{X}$ & $\mathrm{X}$ & $\mathrm{X}$ & $\mathrm{O}$ \\
\hline
\end{tabular}

$\mathrm{X}$ : Turbid bacteria growth found,

$\mathrm{O}$ : Clear bacteria growth not found

Table 2. Dilution Test Cultured into Chocolate Agar Plate

\begin{tabular}{|c|c|c|c|c|c|c|c|c|c|c|}
\hline \multirow{2}{*}{$\begin{array}{l}\text { Replication } \\
\text { No. }\end{array}$} & \multicolumn{8}{|c|}{ Sodium fluoride concentration } & \multicolumn{2}{|c|}{ Control } \\
\hline & $\begin{array}{c}153,6 \\
\mathrm{mg} / \mathrm{ml} \\
(\mathrm{T} 1)\end{array}$ & $\begin{array}{c}76,8 \\
\mathrm{mg} / \mathrm{ml} \\
(\mathrm{T} 2)\end{array}$ & $\begin{array}{c}38,4 \mathrm{mg} / \\
\mathrm{ml} \\
(\mathrm{T} 3)\end{array}$ & $\begin{array}{c}19,2 \mathrm{mg} / \\
\mathrm{ml} \\
(\mathrm{T} 4)\end{array}$ & $\begin{array}{c}9,6 \mathrm{mg} / \\
\mathrm{ml} \\
(\mathrm{T} 5)\end{array}$ & $\begin{array}{c}4,8 \mathrm{mg} / \\
\mathrm{ml} \\
(\mathrm{T} 6)\end{array}$ & $\begin{array}{c}2,4 \mathrm{mg} / \\
\mathrm{ml} \\
(\mathrm{T} 7)\end{array}$ & $\begin{array}{c}1,2 \mathrm{mg} / \\
\mathrm{ml} \\
(\mathrm{T} 8)\end{array}$ & $\begin{array}{c}\text { Positive } \\
(+)\end{array}$ & $\begin{array}{c}\text { Negative } \\
(-)\end{array}$ \\
\hline 1 & + & + & + & - & - & - & + & + & + & - \\
\hline 2 & + & + & + & - & - & - & + & + & + & - \\
\hline 3 & + & + & + & - & - & - & + & + & + & - \\
\hline 4 & + & + & + & - & - & - & + & + & + & - \\
\hline
\end{tabular}

$+:$ Bacteria growth found, $\quad-:$ Bacteria growth not found

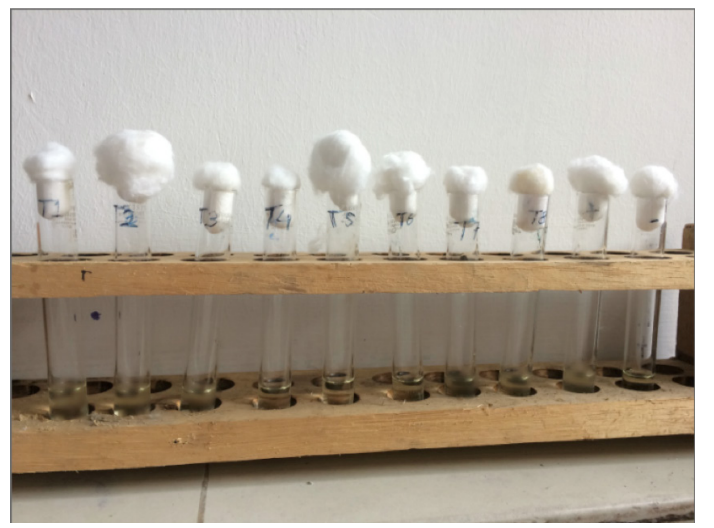

Figure 1. Sodium fluoride dilution test for MIC

Control tubes to compare which tubes were turbid or clear

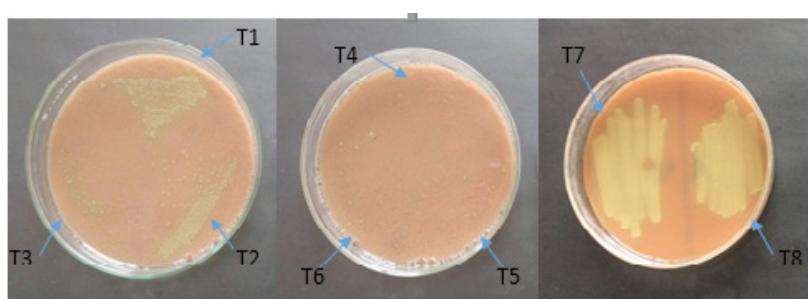

Figure 2. Dilution Test Cultured into Chocolate Agar Plate. In T1 (153,6 mg/ml), T2 (76,8 mg/ml), T3 (38,4 $\mathrm{mg} / \mathrm{ml}), \mathrm{T} 7(2,4 \mathrm{mg} / \mathrm{ml})$, and $\mathrm{T} 8(1,2 \mathrm{mg} / \mathrm{ml})$ culture there were growth of S. mutans. Meanwhile T4 (19,2 mg/ml), T5 $(9,6 \mathrm{mg} / \mathrm{ml})$, and T6 $(4,8 \mathrm{mg} / \mathrm{ml})$ there were no growth of any bacteria. 


\section{Discussion}

Sodium fluoride was used to inhibit enzymes involved in glycolysis ${ }^{3}$ and works effectively in low $\mathrm{pH}$ which leads to inhibiting the metabolism process. $^{8}$ Fluoride can directly inhibits the growth of bacteria. In previous studies it was found that mouth bacteria changes with daily usage of fluoride. It happens because fluoride in this term hydrofluoric acid (HF) will release itself to become $\mathrm{H}+$ and F- in bacteria cell's which leads to accumulation of fluoride in the bacteria cell and will inhibit the metabolism process. ${ }^{9}$ The enzyme which inhibited directly by fluoride is Enolase. High sensitivity to fluoride is the reason why enolase be targeted from the entire process of glycolysis process. ${ }^{10}$ Fermentation which really needed to make the process of glycolysis to be foremost in the $S$. mutans. PEP which is a product of the enzyme enolase be inhibited and decreased production of PEP decrease the growth of these bacteria. ${ }^{6} S$. mutans biofilm formation can occur because the enzyme Exocelullar glucosyltrans-ferases (GTFs). This enzyme can be activated when $S$. mutans stick to a static medium and bind with each other to form arms that strengthen the bond between $S$. mutans. ${ }^{11}$

The conventional concentration of fluoride in toothpaste $(0.08 \%)$ does not give any effect on the growth of $S$. mutans. While high concentrations of 5,000 ppm or 5 $\mathrm{mg} / \mathrm{ml}$ may help reduce biofilm formed12 In studies from Bowden (1990), ${ }^{13}$ the use of high concentrations of fluoride with a range of $3,040 \mathrm{ppm}-5,700 \mathrm{ppm}$ or $3.04 \mathrm{mg} / \mathrm{ml}-5.7$ $\mathrm{mg} / \mathrm{ml}$ are needed to kill bacteria in the mouth. Meanwhile Caufield \& Wannenmuehler (1982), ${ }^{14}$ found that MBC of sodium fluoride on $S$. mutans at $\mathrm{pH}$ 7-8 has a concentration range of 3,500-5,000 ppm or 3.5-5 $\mathrm{mg} / \mathrm{ml}$.

Sodium fluoride gel does not show any antibacterial activity in colonies of S.mutans. The concentration of sodium fluoride needed depends on the $\mathrm{pH}$ of the media. Lower $\mathrm{pH}$ required least concentration of sodium fluoride to have antibacterial effects. Sodium fluoride gel required concentration of $37,000 \mathrm{ppm}$ or $37 \mathrm{mg} / \mathrm{ml}$ in $\mathrm{pH} 3.0$. While only $12,000 \mathrm{ppm}$ or $12 \mathrm{mg} / \mathrm{ml}$ required at $\mathrm{pH} 2.5$ and 1,100 ppm or $1.1 \mathrm{mg} / \mathrm{ml}$ is needed at pH 2.015 . Fluoride works by reducing bacterial tolerance to acids which will most effectively use with lower $\mathrm{pH} .{ }^{16}$

This research found that sodium fluoride at a concentration of $38.4 \mathrm{mg} / \mathrm{ml}$ and higher contained regrowth of $S$. mutans. This can be with form of adaptation from $S$. mutans from the use of high concentration fluoride. ${ }^{17}$ High fluoride concentration will have a quasi-irreversible nature of the inhibitor on the enzyme enolase.

The nature of this inhibition may be returned by the accumulated level of the 2-phosphoglycerate or any products from the PEP. Methods to eliminate fluorideinhibited enolase conduct by forcing to accumulate substrate or products from enolase to bring the reversible effects that help $S$. mutans to stay alive. ${ }^{18}$ It is clear that with the high concentration of sodium fluoride, then $S$. mutans will return to the process of metabolism.

\section{Conclusion}

This research conclude that sodium fluoride has bactericidal effects on $S$. mutans in certain concentration. Sodium fluoride has MIC and MBC at $4,8 \mathrm{mg} / \mathrm{ml}$. Fluoride quasi-irreversible inhibitor effects explain the resistant of $S$. mutans for fluoride in higher concentration.

\section{Conflict of Interest}

The author stated there is no conflict of interest

\section{References}

1. Jawetz E, Melnick J and Adelberg E. Medical Microbiology $24^{\text {th }}$ ed. New York: McGraw-Hill, 2007.

2. Bowden GH. Mutans Streptococci caries and Chlorhexidine. Journal. 1996; 62: 700, 3-7.

3. Subramaniam P and Nandan N. Effect of Xylitol, Sodium Fluoride and Triclosan Containing Mouth Rinse on Streptococcus mutans. Contemporary Clinical Dentistry. 2011; 2: 287-90.

4. Ryan KJ and Ray CG. Sherris Medical Microbiology $1^{\text {st }}$ ed. New York: McGraw- Hill, 2004.

5. Marsh P. Dental Plaque as a Biofilm and a Microbial Community implications for Health and Disease. BMC Oral Health. 2006; 6: S14.

6. Lemos JA, Palmer SR, Zeng L, et al. The Biology of Streptococcus mutans. Microbiology Spectrum. 2019; 7.

7. Association AD. Learn More About Toothpastes. 2007.

8. Zanela NL, Bijella MF and Rosa OP. The Influence of Mouthrinses with Antimicrobial Solutions on the Inhibition of Dental Plaque and on the Levels of Mutans streptococci in Children. Pesquisa Odontologica Brasileira = Brazilian Oral Research. 2002; 16: 101-6.

9. Rosin-Grget K and Lincir I. Current Concept on the Anticaries Fluoride Mechanism of the Action. Collegium Antropologicum. 2001; 25: 703-12.

10. Liao Y, Brandt BW, Li J, Crielaard W, Van Loveren C and Deng DM. Fluoride resistance in Streptococcus mutans: a Mini Review. Journal of Oral Microbiology. 2017; 9: 1344509.

11. Nishimura J, Saito T, Yoneyama H, Lan-Bai L, Okumura K and Isogai E. Biofilm Formation by Streptococcus mutans and Related Bacteria. Advances in Microbiology. 2012; 2: 208-15.

12. Santana G, Silva D, Ferreira J, Rolim F and Vale G. Association of Chlorhexidine and High Fluoride Dentifrice on Streptococcus mutans Viability Using an in Vitro Biofilm Model. Brazilian Dental Science. 2016; 19: 9.

13. Bowden GH. Effects of Fluoride on the Microbial Ecology of Dental Plaque. Journal of Dental Research. 1990; 69 Spec No: 653-9; Discussion 82-3.

14. Caufield P and Wannemuehler Y. In Vitro Susceptibility of Streptococcus mutans 6715 to Iodine and Sodium Fluoride, Singly and in Combination, at Various $\mathrm{pH}$ values,. Antimicrobial Agents and Chemotherapy. 1982; 22: 115-9.

15. Caufield P and Wannemuehler Y. pH-Dependent Bactericidal Effects of Acidulated Fluoride Gels on Preformed Plaque Aggregates of Streptococcus mutans 6715. Antimicrobial Agents and Chemotherapy. 1984; 22: 807-10.

16. Nassar HM and Gregory RL. Biofilm Sensitivity of Seven Streptococcus mutans Strains to Different Fluoride Levels. Journal of Oral Microbiology. 2017; 9: 1328265.

17. Hamilton IR and Bowden GH. Response of Freshly Isolated Strains of Streptococcus mutans and Streptococcus mitior to change in $\mathrm{pH}$ in the Presence and Absence of Fluoride during Growth in Continuous Culture. Infection and Immunity. 1982; 36: 255-62.

18. Curran TM, Buckley DH and Marquis RE. Quasi-irreversible Inhibition of Enolase of Streptococcus mutans by fluoride. FEMS Microbiology Letters. 1994; 119: 283-8. 